\title{
Ganoderma lucidum extract (GLE) impairs breast cancer stem cells by targeting the STAT3 pathway
}

\author{
Tiffany J. Rios-Fuller ${ }^{1}$, Gabriela Ortiz-Soto ${ }^{1}$, Mercedes Lacourt-Ventura ${ }^{1}$, Gerónimo \\ Maldonado-Martinez ${ }^{1}$, Luis A. Cubano ${ }^{1}$, Robert J. Schneider ${ }^{2}$ and Michelle $M$. \\ Martinez-Montemayor ${ }^{1}$ \\ ${ }^{1}$ Universidad Central del Caribe-School of Medicine, Bayamon, Puerto Rico, United States of America \\ ${ }^{2}$ NYU School of Medicine, New York, New York, United States of America
}

Correspondence to: Michelle M. Martinez-Montemayor, email: michelle.martinez@uccaribe.edu

Keywords: triple negative breast cancer; cancer stem cells; aldehyde dehydrogenase; Ganoderma lucidum extract; STAT3

Received: June 30, $2018 \quad$ Accepted: October 24, $2018 \quad$ Published: November 13, 2018

Copyright: Rios-Fuller et al. This is an open-access article distributed under the terms of the Creative Commons Attribution License 3.0 (CC BY 3.0), which permits unrestricted use, distribution, and reproduction in any medium, provided the original author and source are credited.

\section{ABSTRACT}

The aggressive nature of triple negative breast cancer (TNBC) may be explained in part by the presence of breast cancer stem cells (BCSCs), a subpopulation of cells, which are involved in tumor initiation, progression, metastasis, recurrence, and therapy resistance. The signal transducer and activator of transcription 3 (STAT3) pathway participates in the development and progression of BCSCs, but its role in TNBC remains unclear. Here, we report that Ganoderma lucidum extract (GLE), a medicinal mushroom with anticancer activity, acts on BCSCs in vitro and in TNBC preclinical animal tumor models by downregulating the STAT3 pathway. We show that GLE significantly reduces TNBC cell viability, and down-regulates total and phosphorylated STAT3 expression. This is consistent with the reduction of OCT4, NANOG and SOX2 expression, reduction in the BCSC population by loss of the ALDH1 and CD44 / CD24- population, the deformation of mammospheres, and the strong reduction in animal tumor volume and tumor weight. Analysis of the BCSC compartment in tumors revealed that GLE decreases the STAT3 pathway and the expression of OCT4, NANOG, and SOX2 in BCSCs. These findings demonstrate that the anti-cancer activity of GLE targets BCSCs of TNBC through the downregulation of the STAT3 pathway.

\section{INTRODUCTION}

Breast cancer is one of the leading causes of cancer deaths in women worldwide, estimated at one million cases diagnosed with more than 450,000 deaths annually $[1,2]$. The clinically distinct aggressive subtype of breast cancer, triple negative breast cancer (TNBC) lacks estrogen receptors (ER), progesterone receptors (PR), and human epidermal growth factor 2 receptor (HER2) and is characterized by poor outcome [1-4]. TNBC accounts for $15-20 \%$ of all breast cancer cases, predominantly in younger patients ( $<50$ years), distinguished by an increased tumor size and tumor grade, early recurrence, and a lower five-year overall survival rate compared with other breast cancer subtypes [1-5]. To date, treatment options for TNBC patients are chemotherapy and breast-conserving therapy (BCT), since no targeted therapy has shown to be effective for these patients [4-6]. One of the reasons why TNBC tumors are so aggressive may be explained by the presence of breast cancer stem cells (BCSCs) [7].

BCSCs are a small population of cells involved in tumor initiation, proliferation, progression, metastasis, and therapy resistance [8-10]. The major clinical concern with BCSCs is their resistance to chemotherapy, endocrine therapy, and radiotherapy [8]. Moreover, the first tumorigenic BCSCs were identified by the expression of the cell surface marker CD44, and absence of CD24 (CD $\left.44^{+} / \mathrm{CD} 24^{-}\right)$and is associated with poor prognosis [10]. The presence of CD44 promotes tumorigenesis and metastasis in breast cancer, as does the absence of CD24 [9]. An additional BCSC marker is aldehyde dehydrogenase 1 (ALDH1), a detoxifying 
enzyme which is associated with BCSCs and increased malignancy, invasion, and metastasis $[8,9]$. In addition, transcription factors involved in stem cell self-renewal and pluripotency, such as POU class 5 homeobox 1 (POU5F1 [also known as OCT4]), NANOG homeobox (NANOG), and SRY (sex determining region Y)-box 2 (SOX2) proteins, have been shown to be up-regulated in human breast cancer, and their overexpression is linked to cell transformation, tumorigenicity, tumor metastasis, and distant recurrence following chemotherapy $[11,12]$. BCSCs can also be enhanced by growing as spheres (i.e. mammospheres) in serum-free, anchorage-independent, and growth factor-supplemented conditions [13, 14]. Normal human mammary epithelial cells have the ability to form mammospheres, which have an increased number of mammary stem cells and can form a functional mouse mammary gland de novo [15]. In another study, tumors with stem cell markers, CD $44^{+} / \mathrm{CD} 24^{-} / \mathrm{Lin}^{-}$and ALDH1, grown as mammospheres showed an increased capacity for tumor initiation in xenograft models [16].

Many molecular signaling pathways contribute to the properties of BCSCs, including self-renewal, proliferation, survival, and differentiation [17]. According to the literature, the signal transducer and activator of transcription 3 (STAT3) is involved in many cellular processes such as proliferation, survival, anti-apoptosis, invasion, angiogenesis, and metastasis [8, 18]. More importantly, STAT3 has been shown to be highly involved in the development and progression of BCSCs $[8,9]$. Evidence supports that BCSCs with the CD $44^{+} / \mathrm{CD} 24^{-}$ phenotype are regulated by the Janus Kinase 2 (JAK2)/ STAT3 pathway when compared to other breast tumor cells [8]. Furthermore, subpopulations of breast cancer cells that are ALDH1 positive express higher levels of phosphorylated STAT3 (Tyr705) than cells that do not express this stem cell marker [19]. Studies have shown that NANOG together with OCT4 and SOX2, are key transcription factors involved in stem cell potency and self-renewal of embryonic stem cells, in which, OCT4 and SOX2 have been shown to be functionally dependent on STAT3 [20]. NANOG cooperates with STAT3 to maintain pluripotency and self-renewing cells, after down-regulation of NANOG, cell proliferation, colony formation, and migration are reduced in breast cancer cells $[21,22]$. However, it is still unclear how the STAT3 pathway regulates the growth of $\mathrm{CD} 44^{+} / \mathrm{CD} 24^{-}$and ALDH1 positive breast cancer cells in TNBC tumor models. Furthermore, the relationship and functionality between the self-renewal transcription factors NANOG, SOX2, and OCT4 with STAT3 is still ambiguous in TNBC models. Given the involvement of STAT3 in tumorigenesis, the development of novel therapeutic targets against STAT3 becomes a potential opportunity to prevent human malignancies, specifically TNBC.

We have been investigating the novel role of Ganoderma lucidum extract (GLE), also known as Reishi, a medicinal mushroom known for hundreds of years to display anti-cancer activities that has recently shown anti-tumor response and survival in cancer patients in combination with traditional chemotherapy [23]. The anticancer activity of GLE was found previously to reduce cell adhesion, proliferation, survival, and invasion, but without understanding its molecular mechanism [24-26]. GLE significantly decreases TNBC tumor volume in preclinical mouse models [27]. Finally, GLE has also been shown to induce cell cycle arrest and apoptosis in human breast cancer cells [28]. Here we provide the first evidence of a molecular mechanism for GLE antitumor action, demonstrating that it inhibits BCSCs by inhibiting the JAK2/STAT3 pathway and BCSC survival signaling.

\section{RESULTS AND DISCUSSION}

\section{GLE decreases cell viability in TNBC cell lines}

Various oncogenic signaling pathways have been investigated to identify GLE's mechanism of action, including the AKT, MAPK/ERK, mTOR and apoptosis signaling pathways, among others [27, 29-35]. However, although modulation of these pathways has been proven, none of these pathways proved to be primary targets of GLE action.

We first sought to evaluate the effects of GLE on cell viability in the triple negative breast cancer cell line, MDA-MB-231, at increasing concentrations (0.00, 0.06, $0.10,0.25,0.50$, and $1.00 \mathrm{mg} / \mathrm{mL}$ ) of GLE for $24 \mathrm{~h}$. GLE significantly decreased cell viability in a dose-dependent manner by $24 \mathrm{~h}$, with statistically significant reductions initiating at $0.50 \mathrm{mg} / \mathrm{mL}$. The median inhibitory GLE concentration $\left[\mathrm{IC}_{50}\right]$ at $24 \mathrm{~h}$ for MDA-MB-231 cells is 0.96 $\mathrm{mg} / \mathrm{mL}$ (Figure 1A), which is consistent with previous reports demonstrating reduced sensitivity compared to other breast cancer cell lines $[31,36,37]$. The GLE IC In $_{50}$ SUM-149 cells, another triple negative breast cancer cell line, at $24 \mathrm{~h}$ is $0.50 \mathrm{mg} / \mathrm{mL}$ [29]. Importantly, immortalized but not transformed MCF-10A mammary epithelial cells were unaffected at the same time-point and concentration used in these cancer cells [29]. The effect on cell proliferation and viability were quantified for both SUM149 and MDA-MB-231 cells by flow cytometry, treated with $0.1 \%$ DMSO as a vehicle control or at their respective GLE IC $_{50}$ concentrations of $0.50 \mathrm{mg} / \mathrm{mL}$ and $0.96 \mathrm{mg} / \mathrm{mL}$, respectively. GLE significantly decreased the live SUM149 cell population by $54 \%$ and increased the dead cell population by $42 \%$, in comparison with the vehicle treatment (Figure 1B). In MDA-MB-231 cells there was a significant decrease in the live cell population in GLE treated cells when compared to vehicle (Figure 1C). Furthermore, apoptosis is increased in breast tumors with proteins that may promote or inhibit this mechanism such as Survivin, which inhibits caspases and blocks cell death, 
the activation of caspase 3 that cleaves regulatory proteins essential for cell survival and maintenance, and cleavage of poly(ADP-ribose) polymerase (PARP) involved in DNA repair and programmed cell death [38, 39]. Caspase 3 plays a central role in the induction of apoptosis and is responsible for the cleavage of PARP during cell death [39]. Annexin V staining assay by flow cytometry analysis confirmed that GLE significantly decreased the SUM149 live cell population (30.5\%) and increased cells in late apoptosis $(15.2 \%)$ in the SUM-149 cells compared to vehicle (Figure 1D). Our results regarding GLE inducing apoptosis in the SUM-149 cells are confirmed by our immunoblot assays, in which cleaved caspase 3 and cleaved PARP expression are significantly increased in comparison to vehicle (Supplementary Figure 1A and 1B). Our results are also consistent with previous studies, in which GLE induced apoptosis in SUM-149 and other cancer cells [29, 33-35]. In MDA-MB-231 cells, GLE significantly reduced the live cell population $(17.4 \%)$ and significantly increased the dead cell population (10.9\%) when compared to vehicle (Figure 1E). In addition, we examined by Western Blot analysis the expression of Survivin, a protein related to apoptosis, in which GLE significantly decreased the expression compared to vehicle (Supplementary Figure 1C and 1D). Moreover, GLE significantly decreases the expression of Cyclin B1 in MDA-MB-231 cells compared to vehicle (Supplementary Figure 1C and 1D). Cyclin B1, is a protein involved in the transition from the G2 phase to mitosis, and has been found to be overexpressed in many human breast tumors being essential for survival and proliferation [40]. Our results suggest that GLE is triggering cell death by apoptosis or necrosis depending on the cell line at this time point. This is consistent with reports using additional experimental analysis to detect apoptosis, such as Hoechst Staining and DNA fragment assay, which showed that an ethanol-soluble and acidic component (ESAC) prepared from Ganoderma lucidum exerted antiproliferative effects by inducing apoptosis in breast cancer cell lines, including MDA-MB-231 cells [34]. Finally, washout experiments from our laboratory in both cell lines demonstrate that GLE exerts a long-term anti-cancer cell proliferation effect in cancer cell lines when cells did not recover from GLE treatment [32]. Taken together these results demonstrate that GLE significantly decreases cancer cell viability in both TNBC cells lines.

\section{GLE targets STAT3 and transcription factors involved in stemness}

STATs are a large family of transcription factors with the ability to provide instructions that mediate essential chemical signaling pathways that control fundamental functions, such as proliferation, differentiation, angiogenesis, cell death, and immune responses [41]. Among the family of STAT proteins, the transcription factor STAT3 mediates extracellular signaling through the interaction of various ligands with their respective receptors, including Interleukin-6 (IL-6), the most welldefined activator of STAT3 $[42,43]$. Briefly, the binding of the cytokine IL- 6 to its receptor induces receptor dimerization and assembling of JAK proteins, specifically JAK1 and JAK2, to the cytoplasmic domain of the receptor, initiating phosphorylation and activation of the JAK proteins [44]. Then, the activated tyrosine kinase JAK promotes recruitment of STAT3, once JAK and STAT3 are associated, STAT3 becomes phosphorylated on Tyr705 resulting in homodimerization and translocation to the nucleus to initiate transcription of target genes [41]. Interestingly, the JAK2 gene has been found to be amplified in TNBC tumors, and clinical and preclinical studies have shown that the JAK2/STAT3 pathway is constitutively activated in the majority of breast cancer cases, including TNBC [45-49]. STAT3 has been reported to have an essential role in maintaining the expression of genes that are important for stem cell phenotype and used as markers of CSCs [50]. More importantly, years of investigation and a recent article have revealed that the transcription factor NANOG, together with OCT4 and SOX2, play an important role in the development of malignant phenotype cells, and this may be regulated by the activation of STAT3 [51]. Given the significant inhibition of GLE on tumorigenesis and the role of CSCs in this regard, we determined the effect of GLE on the expression and activity of JAK/STAT3 signaling and the transcription factors involved in self-renewal, including OCT4, NANOG and SOX2 [52]. We first sought to determine the effect of GLE in the expression of STAT3 in both our TNBC cell lines. qRT-PCR analysis showed that GLE reduced STAT3 gene mRNA abundance by greater than $50 \%$ in SUM-149 (Figure 2A), and by 35\% in MDAMB-231 cells (Figure 2B). In our immunoblot results, we observe a decrease in phosphorylation of STAT3 at Tyr705 in both TNBC cell lines, with no change in total expression of STAT3 or the phosphorylation of STAT3 at Ser727 (Figure 2C). We show that GLE significantly decreases the phospho/total protein ratio of p-STAT3 Tyr 705 and total STAT3 in both TNBC cell lines (Figure 2D and 2F). Because STAT3 can be activated by JAK1 or JAK2, we studied the effect of GLE upstream of STAT3. In our qRTPCR results, GLE did not reduce JAK2 gene expression in SUM-149 cells, but did decrease the gene expression in MDA-MB-231 cells (Figure 2A and 2B). However, in our immunoblot assays, GLE slightly decreases the expression of JAK1 in SUM-149 cells, and notably decreases the total expression and activation of JAK2 in MDA-MB-231 cells (Figure 2C). This indicates that GLE might be affecting STAT3 by JAK1 in the SUM-149 cells and JAK2 in the MDA-MB-231 cells. Our data is supported since the SUM149 cells are established from primary inflammatory breast cancer (IBC) tumors, and other studies showed that JAK1 and STAT3 are activated in IBC cells compared to non-IBC 
A

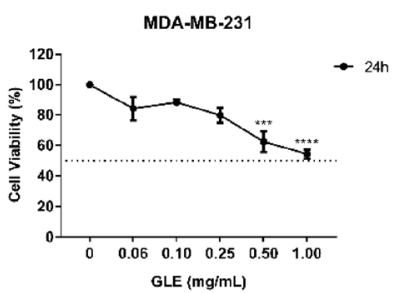

B

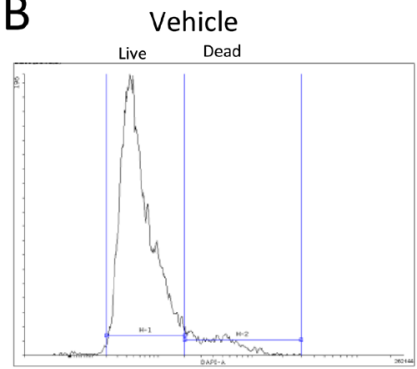

C

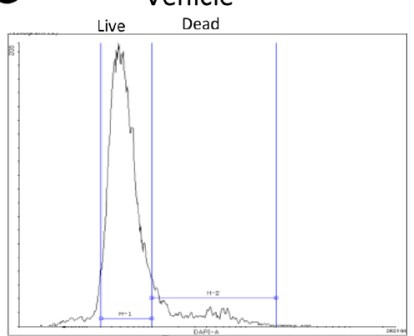

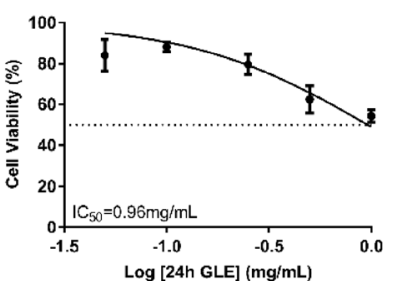

$\log [24 \mathrm{~h} \mathrm{GLE}](\mathrm{mg} / \mathrm{mL})$

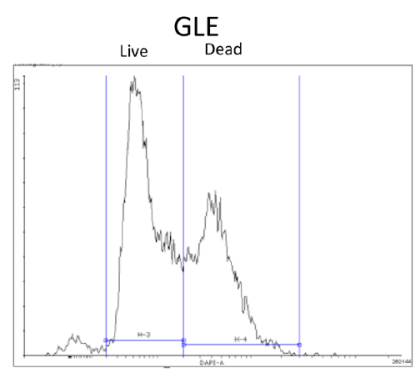

GLE
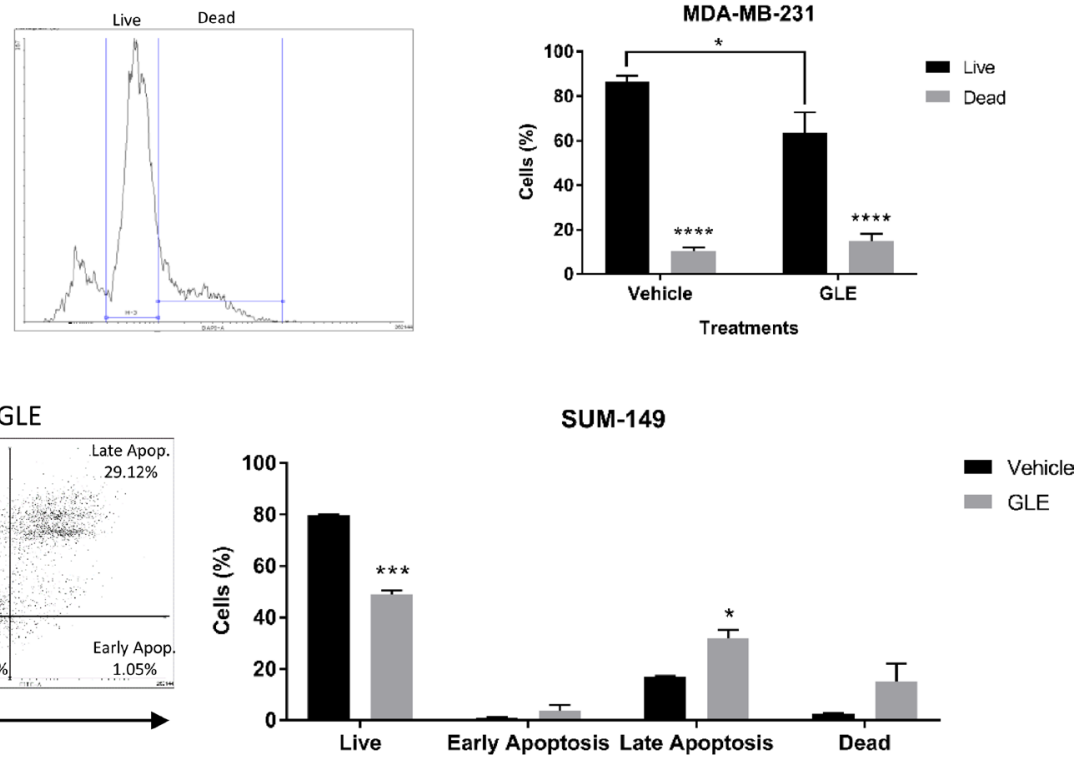

MDA-MB-231
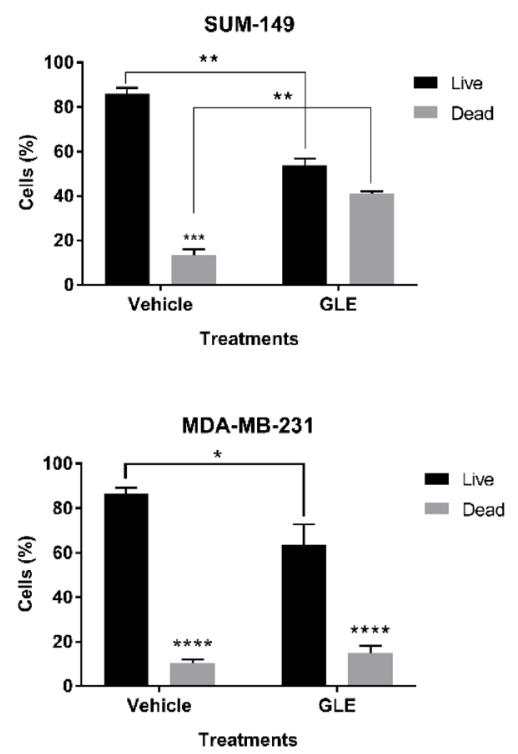

SUM-149

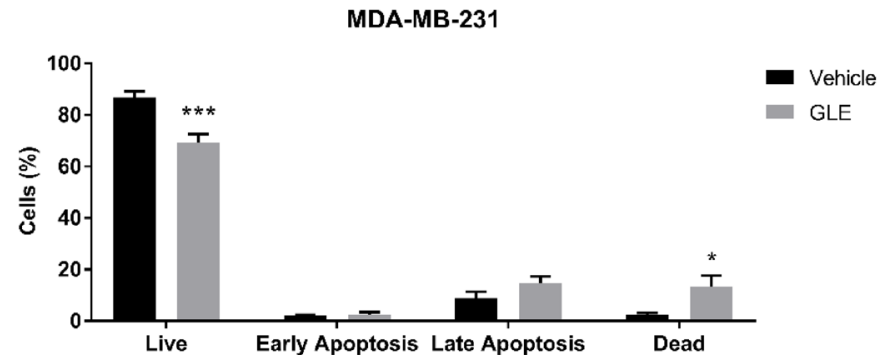

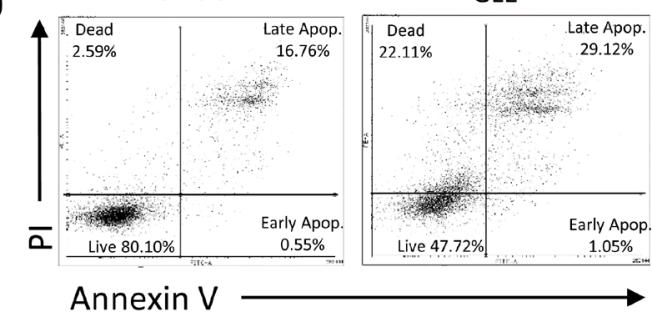

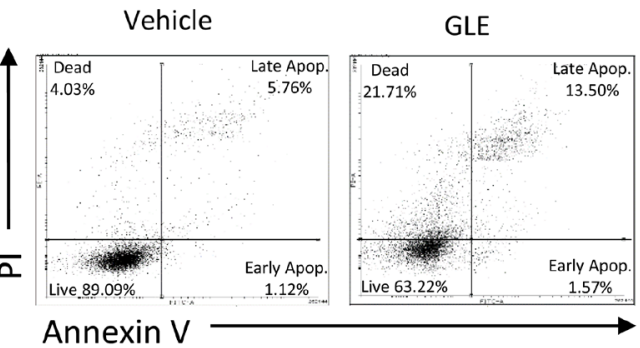

$\mathrm{E}$

Figure 1: GLE decreases cell viability in TNBC cell lines. (A) GLE significantly inhibited cell viability of MDA-MB-231 cells in a dose-dependent manner at $24 \mathrm{~h}$, with a half inhibitory concentration $\left(\mathrm{IC}_{50}\right)$ of $0.96 \mathrm{mg} / \mathrm{mL}$. (B) Live/Dead Staining kit used with the SUM-149 cells revealed that GLE significantly decreased the live cells and increased the dead cells at $24 \mathrm{~h}$. (C) While in the MDA-MB-231 cells, GLE significantly decreased the live cell population. (D) Annexin V/PI staining showed that GLE significantly decreased live cells and increased late apoptotic cells at $24 \mathrm{~h}$ in the SUM-149 cell line. (E) While in the MDA-MB-231 cells, GLE significantly decreases the live cells and increases the dead cells. Columns represent mean \pm SEM from 2 to 3 independent experiments. ${ }^{*} P \leq 0.05 ;{ }^{* *} P<0.01 ;{ }^{* * * *} P<0.001 ;{ }^{* * * *} P<$ 0.0001 , was considered statistically significant compared to vehicle. 
A

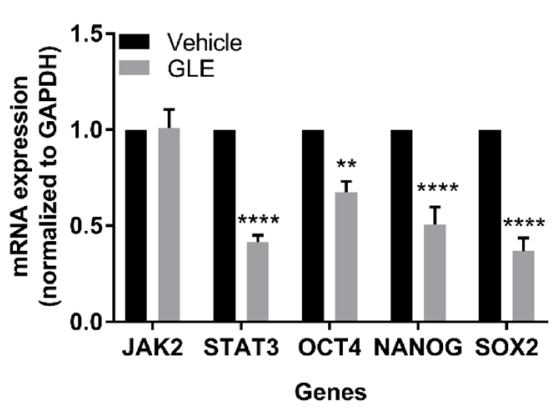

C

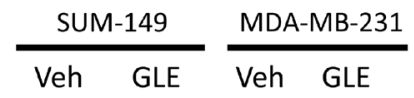

p-JAK1

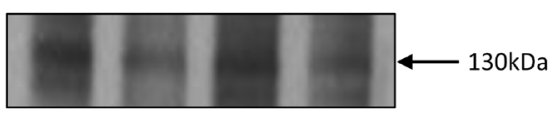

JAK1
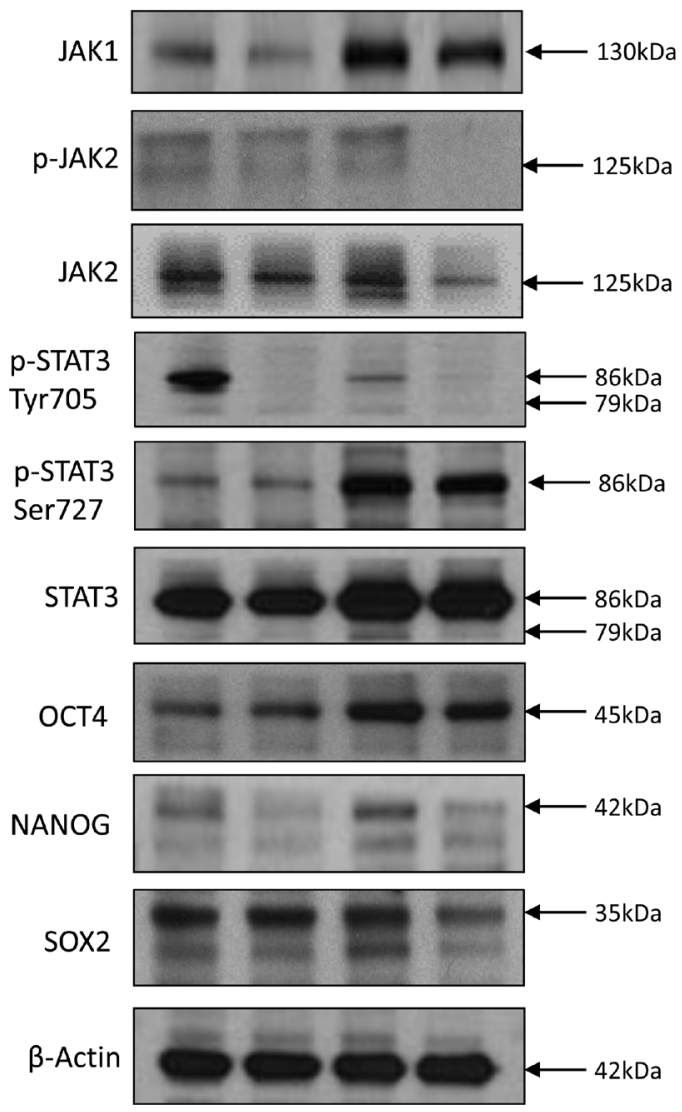

B

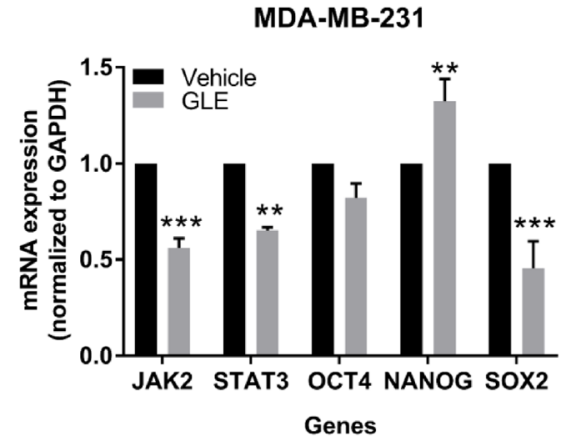

D

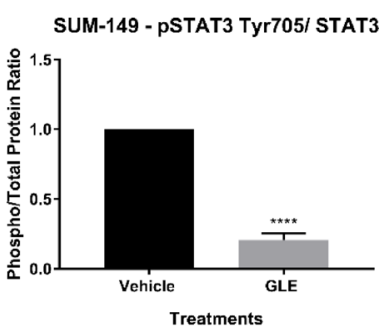

E

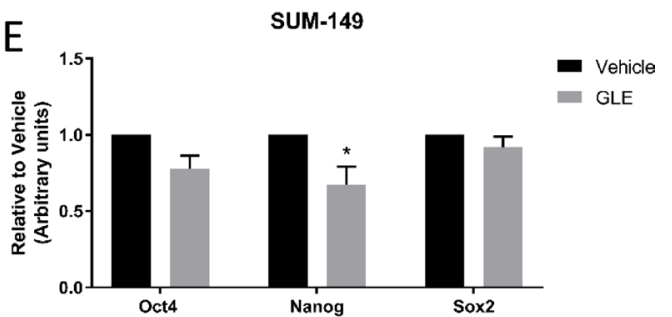

$\mathrm{F}$
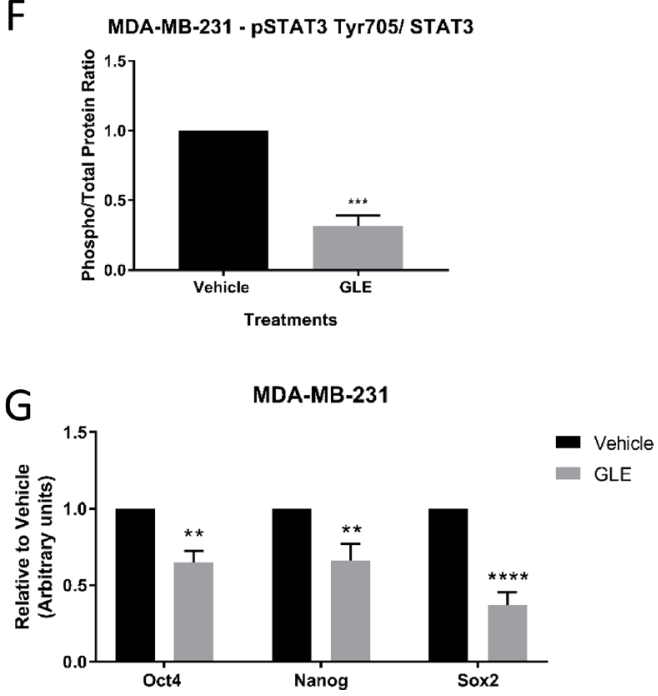

Figure 2: GLE targets STAT3 and transcription factors involved in cancer cell stemness. mRNA expression was measured by qRT-PCR analysis and results were normalized to GAPDH. (A) GLE significantly decreases the gene expression of STAT3, OCT4, NANOG, and SOX2, when SUM-149 cells were treated with GLE at $24 \mathrm{~h}$. (B) The same analyses were carried out for MDA-MB-231 cells at $24 \mathrm{~h}$. Results show that GLE significantly decreases the gene expression of JAK2, STAT3, and SOX2, while increasing the expression of NANOG. (C) Western blot analyses of the selected proteins were analyzed, with results showing (D) GLE significantly decreasing the phosphorylation of STAT3 at Tyr705 and (E) the expression of NANOG in the SUM-149 cells at $24 \mathrm{~h}$ in comparison to vehicle. While in MDA-MB-231 cells, (F) GLE significantly decreases the phosphorylation of STAT3 at Tyr705, and (G) the expression of OCT4, NANOG, and SOX2 in MDA-MB-231 cells compared to vehicle. $\beta$-actin was used as a loading control. Columns represent mean \pm SEM from 3 independent experiments. ${ }^{*} P \leq 0.05 ;{ }^{* *} P<0.01 ;{ }^{* * *} P<0.001 ;{ }^{* * * *} P<0.0001$, was considered statistically significant compared to vehicle. 
cell lines [53]. We continued to measure the expression of the three transcription factors involved in self-renewal and that can be regulated by STAT3. In Figure 2A, GLE significantly decreases the mRNA expression of OCT4, NANOG, and SOX2 in SUM-149 cells. In MDAMB-231 cells, GLE also reduced the mRNA expression of SOX2, but slightly increased expression of NANOG (Figure 2B). We also performed western blot analysis of the three proteins in both TNBC cell lines (Figure 2C). GLE significantly decreased the expression of NANOG in SUM-149 cells compared to vehicle (Figure 2E). Moreover, a significant decrease was obtained in the expression of OCT4, NANOG and SOX2 in the MDAMB-231 cell line at $24 \mathrm{~h}$ in comparison with vehicle (Figure 2C and 2G). GLE, therefore, decreases the expression and activating phosphorylation of STAT3 at Tyr705, which might mediate a decreased expression of the transcription factors involved in self-renewal.

Since the JAK2/STAT3 pathway can be activated by IL-6, we measured IL-6 secretion after treatment with GLE for $24 \mathrm{~h}$. GLE significantly decreased the endogenous secretion of baseline IL-6 in the MDAMB-231 cells but not in SUM-149 cells (Supplementary Figure 1E and 1F). GLE can, therefore, regulate the IL-6/ JAK2/STAT3 pathway in MDA-MB-231 cells, while downregulation of STAT3 in SUM-149 cells occurs by another upstream pathway, which still needs to be investigated (e.g. c-MET, gp130, FGFR, VEGFR, IGFR, or GPCR) [18, 54-56]. GLE inhibition of the IL-6/JAK2/ STAT3 pathway in MDA-MB-231 cells confirms previous findings demonstrating the importance of this pathway in the growth of breast cancer cells [47, 57]. Furthermore, experiments were carried out to investigate the effect of GLE on the JAK2/STAT3 pathway in the MCF-10A cell line. GLE did not alter the expression of JAK2 or STAT3 in these cells (Supplementary Figure 2A and 2B). Moreover, GLE did not affect the protein expression of OCT4, NANOG or SOX2 transcription factors in MCF$10 \mathrm{~A}$ cells (Supplementary Figure $2 \mathrm{~A}$ and $2 \mathrm{C}$ ). Thus, GLE does not reduce the stem cell properties in transformed but not immortalized breast epithelial cells.

\section{GLE reduces ALDH1 activity, the CD44 ${ }^{+} / \mathrm{CD}^{-}$ population and deforms mammospheres in TNBC cells}

STAT3 has been shown to be highly involved in the development and progression of BCSCs and might be a chemoresistance biomarker associated with BCSCs $[8,9,58]$. BCSCs can be identified and isolated by their markers: $\mathrm{CD} 44^{+} / \mathrm{CD} 24^{-}$and increased aldehyde dehydrogenase 1 (ALDH1) activity [9]. In addition, a STAT3 phosphorylation inhibitor (LLL12) reduced the ALDH positive population by apoptosis induction, as well as BCSC-like cell viability, tumorsphere-forming capacity and tumor growth from $\mathrm{ALDH}^{+}$breast cancer cells [19].
We, therefore, examined the effect of GLE inhibition of STAT3 on BCSC properties, including targeting the ALDH1 positive population. GLE significantly decreased ALDH1 activity from $1.13 \%$ to $0.39 \%$ (Figure $3 \mathrm{~A}$ ), almost a 3-fold reduction. Next, we measured the percent population of cells expressing CD44 and CD24 in both TNBC cell lines. We found that the $\mathrm{CD} 44^{+} / \mathrm{CD} 24^{-}$(stem) population of SUM-149 cells was reduced from $14.6 \%$ to $5.2 \%$, and in MDA-MB-231 cells from $94.0 \%$ to $42.5 \%$ (Figure 3B and 3C). Accordingly, GLE increased the CD44-CD24- population from a $4.4 \%$ to $16.6 \%$ in SUM149 cells, and from $0.4 \%$ to $6.5 \%$ in MDA-MB-231 cells. The same experiments were performed in MCF-10A cells, in which GLE did not affect the CD $44^{+} / \mathrm{CD} 24^{-}$(stem) population in comparison to vehicle (Supplementary Figure 2D). We continued to investigate the effect of GLE in mammosphere formation in SUM-149 and MDAMB-231 cells after $24 \mathrm{~h}$ treatment with vehicle and GLE. In Figure 3D, we assessed mammosphere disruption and observed a marked decrease in the sphere size and disintegration in both TNBC cell lines. Moreover, we quantified the circularity of mammospheres in GLE treated TNBC cells. Roundness is a measure of the deviation of the ability of mammospheres to form a perfect circle where lower values indicate less circularity [59-61]. Our results show that GLE significantly decreases circularity of SUM-149 mammospheres (Figure 3E), whereas there was a tendency to a significant decrease in the MDA-MB-231 mammosphere circularity in GLE treated cells compared to vehicle (Figure 3F). According to the literature, mammospheres from different origins (i.e. cell lines or tissues) show a different morphology, where MDAMB-231 cells displays lower mammosphere formation efficiency (MEF) compared to other breast cancer cell lines [62]. We next investigated the mRNA expression of STAT3 in mammospheres by quantitative RT-PCR. GLE treatment decreased STAT3 mRNA expression by $30 \%$ in SUM-149 cells, and by $61 \%$ in MDA-MB-231 cells when compared with vehicle (Figure 3G). These data suggest that down-regulation of STAT3 by GLE selectively targets the BCSC population in TNBC cells.

\section{GLE decreases $\mathrm{CD}^{+} 4^{+} / \mathrm{CD}^{-} 4^{-}$tumor growth and inhibits the STAT3 signaling pathway in vivo}

As previously described, the STAT3 pathway plays a crucial role in the maintenance of BCSCs, as does the IL-6/JAK2/STAT3 pathway and increased expression of ALDH1 [8, 9, 63]. Inhibition of STAT3 also suppressed tumor growth and reduced the ALDH positive breast cancer stem cell population in mouse xenograft models [15]. As we have shown in this study and previously, MDA-MB-231 cells harbor more than $90 \%$ of $\mathrm{CD}_{4}^{+} /$ CD24- population and have a higher STAT3 activation than other breast cancer cell lines $[64,65]$. We, therefore, examined the tumor therapeutic potential of GLE on 
A
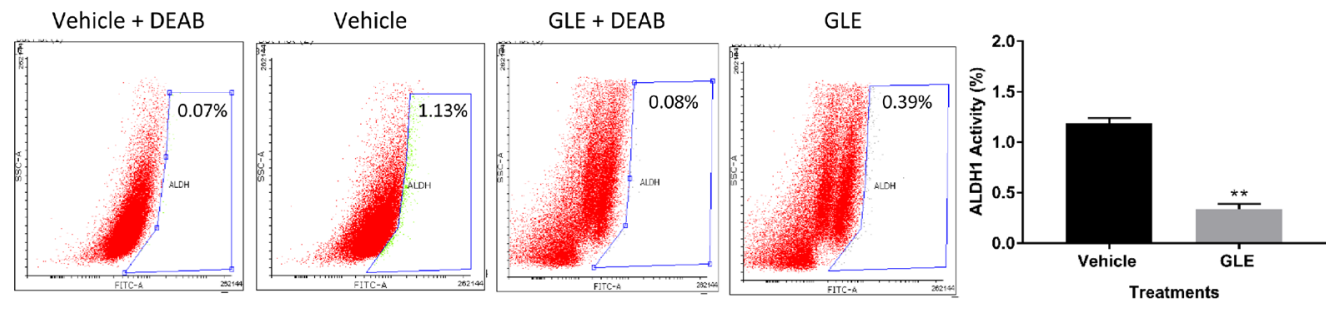

B

GLE
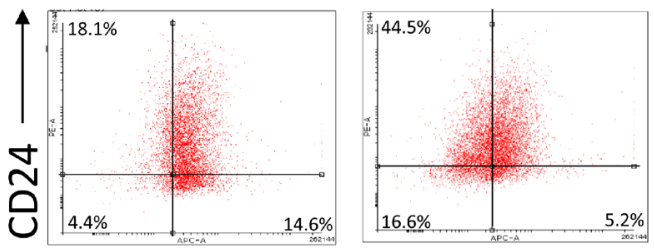

CD44

C
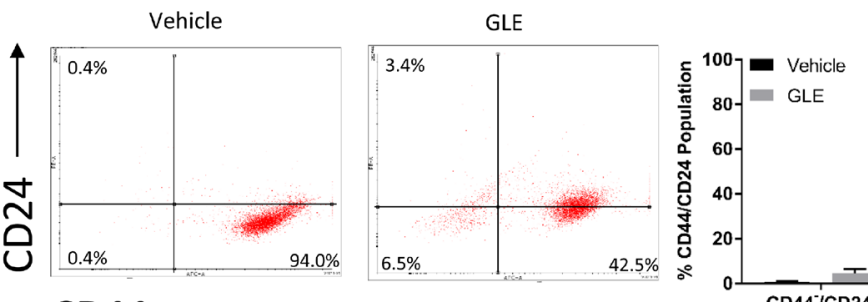

MDA-MB-231

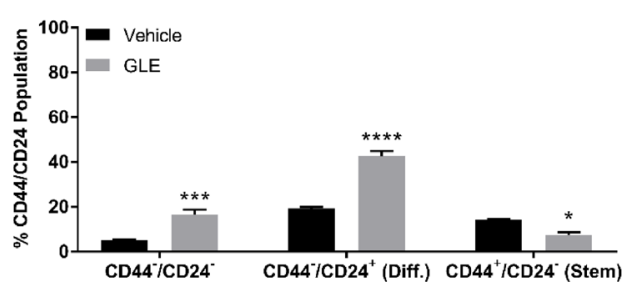

CD44

$\mathrm{CD}^{-} / \mathrm{CD} 24^{\circ} \quad \mathrm{CD}_{4} 4^{\circ} / \mathrm{CD}^{\prime} 4^{+}$(Diff.) $\mathrm{CD}^{+} / \mathrm{CD}^{-} 4^{-}$(Stem

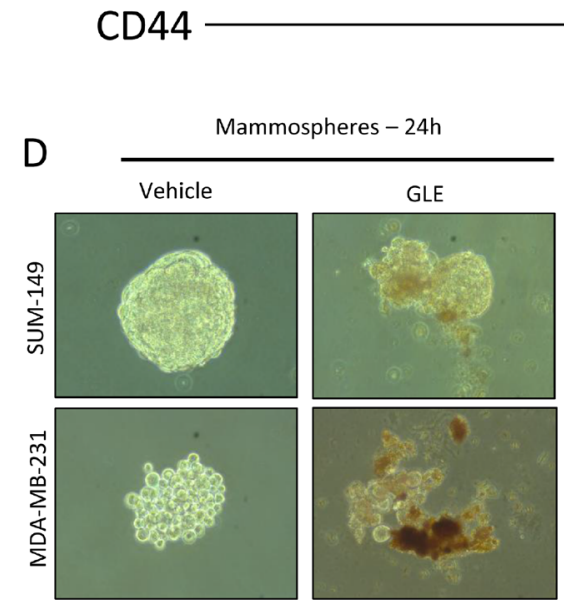

E

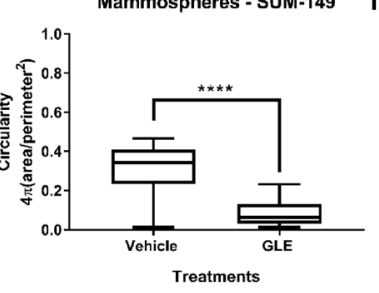

F Mammospheres - MDA-MB-231

G
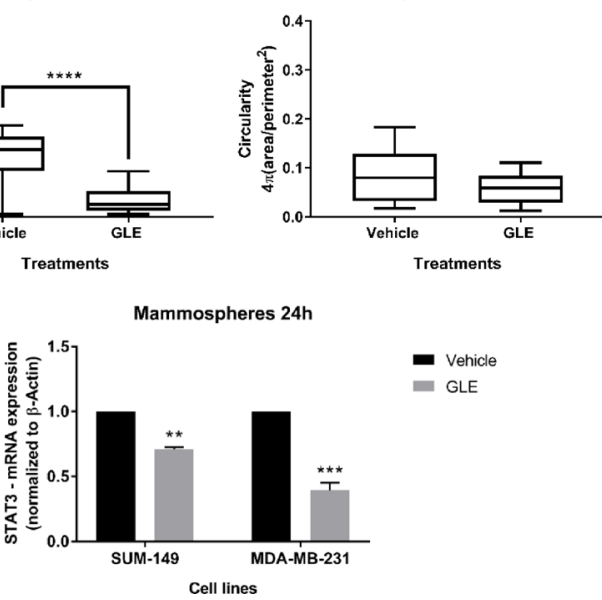

Figure 3: GLE reduces ALDH1 activity, $\mathrm{CD44}^{+} / \mathrm{CD}^{-}$population, and deforms mammospheres in TNBC cells. (A) FACS images and quantified results of ALDH1 activity in MDA-MB-231 cells at $24 \mathrm{~h}$ reveal that GLE significantly decreases ALDH1 activity, compared to vehicle. (B) Representative flow cytometry dot plots of CD44 and CD24 expression in SUM-149 cells treated with GLE at $24 \mathrm{~h}$ show a significant increase in double-negative stained cells and a decrease in the CD44 ${ }^{+} / \mathrm{CD} 24^{-}$(stem cell) population. (C) The statistical analyses performed in the MDA-MB-231 cells display that GLE significantly decreases the CD $44^{+} / \mathrm{CD} 24^{-}$population at $24 \mathrm{~h}$ in comparison to vehicle. (D) TNBC cell lines were seeded to form mammospheres in non-serum non-adherent culture conditions in the absence (Vehicle) or presence of GLE, with results showing a decrease in size and deformation of the mammospheres at $24 \mathrm{~h}$. (E) Quantification of the circularity for SUM-149 mammospheres shows that GLE significantly decreases the circularity at $24 \mathrm{~h}$ compared to vehicle, $(\mathbf{F})$ while in the MDA-MB-231 mammospheres, GLE shows a tendency $(P<0.07)$ to decrease circularity compared to vehicle. (G) mRNA expression of STAT3 was measured by qRT-PCR analysis after mammospheres were treated with vehicle and GLE, with results showing that GLE significantly decreases the gene expression of STAT3 in both TNBC cell lines compared to vehicle. Results were normalized to $\beta$-actin. Columns represent mean \pm SEM from 2 or 3 independent experiments. Data for the circularity analysis are from $n=20$ replicates from 3 independent experiments. ${ }^{*} P \leq 0.05 ;{ }^{* *} P<0.01 ;{ }^{* * *} P<0.001 ;{ }^{* * * *} P<0.0001$, was considered statistically significant compared to vehicle. 
STAT3 signaling and BCSC stemness and viability in MDA-MB-231 cells. We found that GLE does not alter mouse weight compared to vehicle, indicating a lack of systemic toxicity (Figure 4A). Importantly, GLE significantly suppressed tumor volume $(P<0.05)$ and tumor weight $(P=0.05)$ in mice injected with sorted CD $44^{+} / \mathrm{CD} 24^{-}$breast cancer stem-like cells (Figure 4B and $4 \mathrm{C}$ ). Immunoblot analysis revealed a significant decrease in the phosphorylation of JAK2 at Tyr1007/1008 in tumors of mice treated with GLE, as well as in the expression of total STAT3 and phosphorylation of STAT3 at Tyr705 (Figure 4D and 4E). Finally, we measured the expression of all three transcription factors. In our results, there were no significant changes in the expression of all three stemness transcription factors (OCT4, NANOG, and SOX2) compared to vehicle alone (Figure 4D and 4F). These data contrast with in vitro results and might be a result of the interaction of the cancer stem cells with the tumor microenvironment, which has been shown to induce plasticity of cancer stem cells in cancer models [66]. As we showed in our in vitro results, GLE is targeting the BCSCs in tumors through downregulation of STAT3 and significantly decreases tumor volume and weight of BCSCs of the TNBC cell line, MDA-MB-231.

In summary, we observed that GLE is impairing the cell viability of TNBC cells by programmed cell death. GLE is significantly suppressing multiple properties of BCSCs such as decreasing the ALDH1 population and the $\mathrm{CD} 44^{+} / \mathrm{CD} 24^{-}$stem-like population, inducing mammosphere deformation and decreasing circularity, and blocking self-renewal transcription factors expression through inhibition of STAT3 signaling. Also, GLE significantly decreased tumor volume and weight from mice injected with sorted (i.e. CD $44^{+} / \mathrm{CD} 24^{-}$) breast cancer stem cells, and significantly decreased the activation of STAT3 in these xenograft's tumors. These results suggest that GLE may be a potential novel treatment for TNBC by targeting the BCSCs population in vitro and in vivo.

\section{MATERIALS AND METHODS}

\section{Cell culture}

Three breast cancer cell lines, MDA-MB-231 (ATCC $^{\circledR}$ HTB-26 $^{\mathrm{TM}}$ ), SUM-149 (Asterand Bioscience, Detroit, MI, USA), and MCF-10A (ATCC ${ }^{\circledR}$ CRL-10317 $7^{\mathrm{TM}}$ ) characterized for their negativity for ER, PR, HER2 molecular classification were used [2]. MDA-MB-231 cells were obtained from the American Type Culture Collection (ATCC, Manassas, VA, USA) and grown in Dulbecco's modified Eagle's medium (DMEM, Corning, Corning, NY, USA) containing 10\% fetal bovine serum (FBS). The SUM-149 cells were obtained from Dr. Steven Ethier, Medical University of South Carolina (Charleston, SC), and grown in RPMI-1640 (Gibco -
Thermo Fisher Scientific, Waltham, MA, USA) with 5\% FBS [27]. Human mammary epithelial MCF-10A cells were obtained from ATCC (Manassas, VA, USA) and were grown in DMEM and Ham's F12 medium with 10\% horse serum (Millipore Sigma, St. Louis, MO, USA). All cells lines were incubated at $37^{\circ} \mathrm{C}$ in an atmosphere of $5 \% \mathrm{CO}_{2}$ [29]. All cell lines were tested regularly to ensure they were free from mycoplasma infection using the Mycoplasma Detection Kit (ASB-1310001, Nordic BioSite $\mathrm{AB}$, Sweden). In addition, both triple negative breast cancer cell lines were genotyped for authenticity using the Short tandem repeat (STR) profile and interspecies contamination testing services from IDEXX BioResearch (Columbia, MO, USA).

\section{Ganoderma lucidum extract}

Whole mushroom Ganoderma lucidum extract (GLE) was purchased from Pharmanex ${ }^{\circledR}$ (Provo, UT). This commercially available mushroom contains $13.5 \%$ polysaccharides, $6 \%$ triterpenes, and $1 \%$ cracked spores as described by us $[27,29]$. The extract is available in capsules, where the contents were prepared at a working stock of $100 \mathrm{mg} / \mathrm{mL}$, dissolved in $10 \%$ sterile Dimethyl Sulfoxide (DMSO) diluted $(1: 10, \mathrm{v} / \mathrm{v})$ with media. The product and effective concentrations for the cells have been chosen after a literature review, and after performing dose-response curves [29]. We conduct characterization studies with FTIR, GC/MS, Cyclic Voltammetry, to ensure and assess product stability, batch-to-batch characterization, and batch-to-batch variability.

\section{Cell viability assay}

Cells $\left(6 \times 10^{4}-1.5 \times 10^{5}\right.$ cells/well $)$ were seeded and cultured for $24 \mathrm{~h}$. Then, the cells were treated in duplicates with 2-fold serial dilutions of GLE for $24 \mathrm{~h}$. Cells were fixed in cold $100 \%$ methanol, and nuclei stained $[0.4 \%$ propidium iodide (PI)] (Millipore Sigma), and measured using a GloMax ${ }^{\circledR}$ Microplate Reader (Promega, Madison, WI, USA) [29]. Cell viability was calculated as the percent of surviving cells after treatment relative to vehicle $(0.1 \%$ DMSO) wells.

\section{Live and dead assay}

Cells were analyzed using the LIVE/DEAD ${ }^{\mathrm{TM}}$ Fixable Dead Cell Stain Kits (\#L23105, Invitrogen Thermo Fisher Scientific) according to the manufacturer's protocol. Cells $\left(5 \times 10^{5}\right.$ cells/plate $)$ were seeded for $48 \mathrm{~h}$, and then treated with vehicle or $[0.5 \mathrm{mg} / \mathrm{mL}$ for SUM-149 or $0.96 \mathrm{mg} / \mathrm{mL}$ for MDA-MB-231] of GLE for $24 \mathrm{~h}$. Then harvested and rinsed in $1 \mathrm{~mL}$ of phosphate buffer saline (PBS), followed by resuspension of $1 \times 10^{6}$ cells $/ \mathrm{mL}$ in PBS. Cells were incubated with $1 \mu \mathrm{L}$ of the reconstituted fluorescent reactive dye at room temperature for $30 \mathrm{~min}$ in the dark. The samples were analyzed in a Becton 

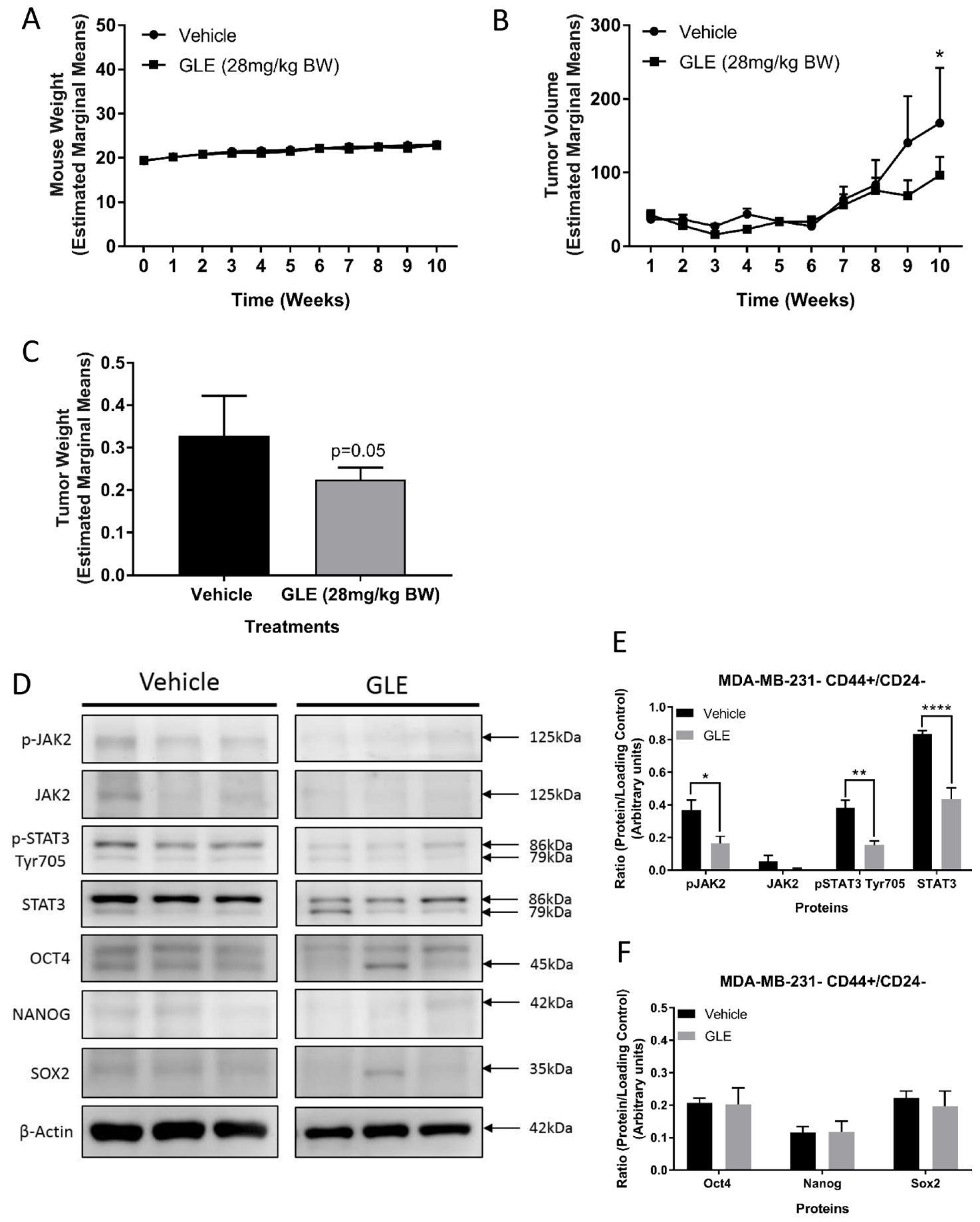

Figure 4: GLE decreases $\mathrm{CD}^{+} / \mathrm{CD}^{+} 4^{-}$tumor growth and inhibits the STAT3 signaling pathway in vivo. (A) Average mouse weights of each group. GLE treated group and vehicle treated group showed no significant differences in mouse weight. (B) The graph represents average tumor volumes of each group over time (10 weeks). The average tumor volume from GLE treated mice significantly decreased in comparison to the vehicle treated group. Bar represents tumor volume mean $\pm \operatorname{SEM}(n=7$ mice, $P<0.05)$. (C) Average tumor weights of each group. The average tumor weight from GLE treated group was significant in comparison to the vehicle treated group (mean \pm SEM, $n=7, p=0.05$ ). (D) Western blot assays of GLE effects in BCSCs tumors. (E) GLE decreases phosphoJAK2 (Tyr1007/1008), phospho-STAT3 (Tyr705), and total STAT3. (F) GLE does not change the expression of the three transcription factors (OCT4, NANOG, and SOX2) in BCSCs tumors. Total proteins were extracted from tumor tissues. Immunoblots were performed on three independent experiments with indicated antibodies. $\beta$-actin was used as a loading control. Columns represent mean \pm SEM from 3 independent experiments. ${ }^{*} P \leq 0.05 ;{ }^{* *} P<0.01 ;{ }^{* * *} P<0.001 ;{ }^{* * * *} P<0.0001$, was considered statistically significant compared to vehicle. 
Dickinson BD ${ }^{\mathrm{TM}}$ LSR II UV flow cytometry cell analyzer (Becton, Dickinson and Company, Franklin Lakes, NJ, USA).

\section{Immunoblot analysis}

Cells $\left(5 \times 10^{5}\right.$ cells/plate $)$ were seeded for $48 \mathrm{~h}$, and then treated with vehicle or $[0.5 \mathrm{mg} / \mathrm{mL}$ for SUM149 or $0.96 \mathrm{mg} / \mathrm{mL}$ for MDA-MB-231] of GLE for $24 \mathrm{~h}$, then washed with PBS and solubilized in RIPA buffer (150 mM NaCl, $50 \mathrm{mM}$ Tris $\mathrm{pH}$ 8.0, 1\% NP-40) containing Halt Phosphatase Inhibitor Cocktail (Thermo Fisher Scientific) and Protease Inhibitor Tablet (Roche Diagnostics Corporation, Indianapolis, IN, USA), and incubated for $10 \mathrm{~min}$ on ice. Supernatants were collected after centrifugation (13,000 $\left.\mathrm{RPM}, 4^{\circ} \mathrm{C}, 10 \mathrm{~min}\right)$ and protein concentrations were measured with a BCA protein assay kit (Thermo Fisher Scientific). Equal quantities of protein $(30 \mu \mathrm{g})$ were subjected to sodium dodecyl sulfatepolyacrylamide gel electrophoresis (SDS-PAGE) and electrotransferred onto a PVDF membrane (Immobilon ${ }^{\circledR}$-P, Millipore Sigma). The membranes were blocked with BSA $5 \%$ and incubated at $4^{\circ} \mathrm{C}$ with primary antibodies purchased from Cell Signaling Technology (Danvers, MA, USA). They include JAK1 (\#3332), Phospho-JAK1 (Tyr1022/1023) (\#3331), JAK2 (\#3230), Phospho-JAK2 (Tyr1007/1008) (\#3771), STAT3 (\#12640), PhosphoSTAT3 (Tyr705) (\#9145), Phospho-STAT3 (Ser727) (\#9134), OCT4 (\#2750), NANOG (\#3580), SOX2 (\#2748), Caspase 3 (\#9662), Cleaved Caspase 3 (Asp175) (\#9664), PARP (\#9542), Cleaved PARP (Asp214) (\#5625), Survivin (\#2808), and as a loading control $\beta$-Actin (\#4967). All antibodies were diluted in 5\% BSA. Followed by incubation with ECL-conjugated anti-rabbit or antimouse IgGs (1:10,000) (GE Healthcare, Chicago, IL, USA). Signal intensity was detected using an Enhanced Chemiluminescence Kit (PerkinElmer, Madrid, Spain) and X-ray film (Denville Scientific Inc., Holliston, MA, USA).

\section{Enzyme-linked immunosorbent assay (ELISA) of Interleukin-6 (IL-6)}

Cells $\left(5 \times 10^{5}\right.$ cells/plate) were seeded for $48 \mathrm{~h}$, and then treated with vehicle $(0.1 \%$ DMSO) or $[0.5 \mathrm{mg} / \mathrm{mL}$ for SUM-149 or $0.96 \mathrm{mg} / \mathrm{mL}$ for MDA-MB-231] of GLE for $24 \mathrm{~h}$. After $24 \mathrm{~h}$ treatment time, the supernatant was collected. The differential expression of IL-6 was determined using a Multi-Analyte ELISArray (QIAGEN, Germantown, MD, USA) following the manufacturer's instructions. The assay was done in duplicates. A Glomax ${ }^{\circledR}$ Multi Detection System (Promega) was used for the analysis.

\section{Real-time quantitative RT-PCR analysis of endogenous mRNAs}

Total RNA was extracted from cells using Trizol reagent (Gibco - Thermo Fisher Scientific), according to the manufacturer's instructions. RNA concentration and purity were quantified using a NanoDrop (NanoDrop Technologies, Wilmington, DE, USA). RNA purity was obtained by the spectral parameter and by the analysis of 260/280 and 260/230 ratio. First-strand cDNA was synthesized from $1 \mu \mathrm{g}$ of total RNA using the High-Capacity cDNA Reverse Transcription Kit (Applied BiosystemsThermo Fisher Scientific) following the manufacturer's instructions. Real-time quantitative PCR (qPCR) analysis was performed using $500 \mathrm{ng}$ cDNA, $500 \mathrm{nM}$ primers (Table 1), and Maxima SYBR Green qPCR Master Mix (2×) (Bio-Rad Laboratories, Hercules, CA, USA). The samples were analyzed with an Applied Biosystems ${ }^{\circledR} 7500$ Real-Time PCR Systems (Thermo Fisher Scientific).

\section{Annexin V/PI assay}

After $24 \mathrm{~h}$ treatment with vehicle (0.1\% DMSO) or GLE $[0.5 \mathrm{mg} / \mathrm{mL}$ for SUM-149 or $0.96 \mathrm{mg} / \mathrm{mL}$ for MDAMB-231], cells were analyzed with a FITC-conjugated Annexin V Apoptosis Detection Kit I (\#556547, Becton, Dickinson and Company, USA) according to the manufacturer's protocol. Cells were harvested and rinsed in cold PBS, followed by resuspension of $1 \times 10^{6}$ cells $/ \mathrm{mL}$ in $1 \mathrm{X}$ Annexin Binding Buffer. $1 \times 10^{5}$ cells were incubated with $5 \mu \mathrm{L}$ of FITC Annexin V (51-65874X, Becton, Dickinson and Company, USA) and $5 \mu \mathrm{L}$ of PI (51-66211E, Becton, Dickinson and Company, USA) at room temperature for $15 \mathrm{~min}$ in the dark. In each sample $400 \mu \mathrm{L}$ of $1 \mathrm{X}$ Annexin Binding Buffer was added. The samples were analyzed with a Becton Dickinson BD ${ }^{\mathrm{TM}}$ LSR II UV flow cytometry cell analyzer (Becton, Dickinson and Company, USA).

\section{Aldefluor assay}

The ALDEFLUOR ${ }^{\mathrm{TM}}$ assay kit (\#01700, StemCell'TM Technologies, Vancouver, BC) was used to assess ALDH enzymatic activity according to the manufacturer's protocol. Briefly, after $24 \mathrm{~h}$ treatment, SUM-149 and MDA-MB-231 cells were incubated for $40-45 \mathrm{~min}$ at $37^{\circ} \mathrm{C}$ in ALDEFLUOR assay buffer containing the ALDH protein substrate BODIPY-aminoacetaldehyde (BAAA, $1 \mu \mathrm{M}$ per $1 \times 10^{6}$ cells). As a specific inhibitor of ALDH, $50 \mathrm{mM}$ diethylamino-benzaldehyde (DEAB) was used as a negative control. Aldefluor stained cells were analyzed with a Becton Dickinson BD ${ }^{\text {TM }}$ LSR II UV flow cytometry cell analyzer (Becton, Dickinson and Company, USA).

\section{$\mathrm{CD}^{+} / \mathrm{CD}^{-} 4^{-}$staining analysis}

CD $44^{+} / \mathrm{CD} 24^{-}$staining analysis was used to identify CSC-like cell populations. After $24 \mathrm{~h}$ treatment, a total of $2.5 \times 10^{3}$ cells were incubated in the dark for 35-40 min at $4^{\circ} \mathrm{C}$ with PE-conjugated anti-human CD24 (\#555428, BD Pharmingen ${ }^{\mathrm{TM}}$ ) and APC-conjugated anti-human CD44 (\#559942, BD Pharmingen ${ }^{\mathrm{TM}}$ ) antibodies. Unbound 
Table 1: List of primers for real-time qPCR analyses

\begin{tabular}{|c|c|c|c|}
\hline Gene & NCBI RefSeq & Primer sequence $(\mathrm{F})$ : & Primer sequence $(\mathbf{R})$ : \\
\hline $\begin{array}{l}\text { Janus Kinase } 2 \\
(J A K 2)\end{array}$ & NM_004972.3 & TAG ATG AGT CAA CCA GGC ATA ATG & CCG CCA CTG AGC AAA GAG \\
\hline $\begin{array}{l}\text { Signal Transducer } \\
\text { and Activator Of } \\
\text { Transcription } 3 \\
\text { (STAT3) }\end{array}$ & NM_139276.2 & AGC AGC TTG ACA CAC GGT A & AAA CAC CAA AGT GGC ATG TGA \\
\hline $\begin{array}{l}\text { POU Class } 5 \\
\text { Homeobox } 1 \\
\text { (POU5F1, also } \\
\text { known as OCT4) }\end{array}$ & NM_002701.4 & AGC AAA ACC CGG AGG AGT & CCA CAT CGG CCT GTG TAT ATC \\
\hline $\begin{array}{l}\text { NANOG } \\
\text { Homeobox } \\
(\text { NANOG) }\end{array}$ & NM_024865.2 & ATG CCT CAC ACG GAG ACT GT & AGG GCT GTC CTG AAT AAG CA \\
\hline SRY-Box 2 (SOX2) & NM_003106.3 & GCC GAG TGG AAA CTT TTG TCG & GCA GCG TGT ACT TAT CCT TCT T \\
\hline $\begin{array}{l}\text { Actin Beta } \\
(\beta \text {-Actin) }\end{array}$ & NM_001101.4 & CTT CCT TCC TGG GCA TG & GTC TTT GCG GAT GTC CAC \\
\hline $\begin{array}{l}\text { Glyceraldehyde- } \\
\text { 3-Phosphate } \\
\text { Dehydrogenase } \\
\text { (GAPDH) }\end{array}$ & NM_002046.3 & ATG GGG AAG GTG AAG GTC G & GGG GTC ATT GAT GGC AAC AAT A \\
\hline
\end{tabular}

Abbreviations: RefSeq, Reference Sequence; F, Forward; R, Reverse.

antibody was washed off and cells were analyzed by flow cytometry on a Becton Dickinson BD ${ }^{\mathrm{TM}}$ LSR II UV flow cytometry cell analyzer (Becton, Dickinson and Company, USA).

\section{Mammosphere formation assay}

SUM-149 cells for mammosphere formation were cultured in Ham's F-12 medium containing 20 ng/mL EGF (Sigma), $20 \mathrm{ng} / \mathrm{mL}$ basic FGF (Fisher Scientific), 1X B27 (Invitrogen), $4 \mathrm{ng} / \mathrm{mL}$ Heparin (Sigma), $5 \mu \mathrm{g} / \mathrm{mL}$ insulin, $1 \mu \mathrm{g} / \mathrm{mL}$ hydrocortisone, 100 units/mL penicillin and 100 units/mL streptomycin. The MDA-MB-231 were cultured in HuMEC basal serum-free medium (Gibco), supplemented with B27 (1:50, Invitrogen, Carlsbad, CA, USA), $20 \mathrm{ng} / \mathrm{mL}$ basic fibroblast growth factor (bFGF, Sigma-Aldrich), $20 \mathrm{ng} / \mathrm{mL}$ human epidermal growth factor (EGF, SigmaAldrich), $4 \mu \mathrm{g} / \mathrm{mL}$ heparin, $1 \%$ antibiotic-antimycotic agent, and $15 \mu \mathrm{g} / \mathrm{mL}$ gentamycin. Cells were trypsinized, passed through a $40 \mu \mathrm{m}$ cell strainer (BD Falcon), seeded in ultralow attachment plates (Corning), cultured for 7-10 days at a density of 10,000 cells/mL for SUM-149 and 5,000 cells/ $\mathrm{mL}$ for the MDA-MB-231 cells and the experiments were performed after the 3rd passage. The mammospheres were treated with vehicle or GLE for $24 \mathrm{~h}$ and analyzed using an inverted microscope. Photos were acquired with ZEN software from ZEISS Microscopy (Oberkochen, Germany). Circularity was calculated using the formula $4 \pi$ (Area/ Perimeter ${ }^{2}$ ) using Image J [59-61, 67].

\section{In vivo study}

To test tumorigenicity we injected limiting dilutions of $5.0 \times 10^{3}$ sorted $\left(\mathrm{CD}_{4} 4^{+} / \mathrm{CD} 24^{-}\right) \mathrm{MDA}-\mathrm{MB}-231 \mathrm{BCSCs}$ cells in $100 \mu \mathrm{L}$ of Matrigel (CB-40230A, BD Biosciences, San Jose, CA, USA) solution (1:1 dilution of Matrigel with DMEM medium), into $7 \mathrm{mice} /$ group to achieve adequate statistical power. The cells were injected into the mammary fat pad of 4-wk-old female severe combined immunodeficient (SCID) mice [Charles River Laboratories International (Wilmington, MA, USA)]. One-week postinoculation, mice were randomly divided into vehicle and GLE experimental groups. The treatments began once palpable tumors were detected ( $\sim 1$ wk post-inoculation). Mice were orally gavaged every day with vehicle or 28 $\mathrm{mg} / \mathrm{kg} \mathrm{BW}$ of GLE in $10 \%$ ethanol for $10 \mathrm{wks}$. Mice were housed under specific pathogen-free conditions, were given 2920X Teklad Global Rodent Diet (Harlan Laboratories, Indianapolis, IN, USA) and sterile water. Mouse weights and tumor volume (calipers measurements) were measured weekly. Tumor volume $\left(\mathrm{mm}^{3}\right)$ was calculated: $[\pi / 6(\mathrm{~L})(\mathrm{W})(\mathrm{H})]$. Relative tumor volume was calculated as [(average tumor volume ratio on week " $n$ ")/ average tumor volume on week-1]. Mice were housed and handled in accordance with the Universidad Central del Caribe School of Medicine, Institutional Animal Care and Use Committee (UCC-IACUC), and the National Institute of Health (NIH) principles and guidelines. 


\section{Statistical analysis}

For in vitro experiments; normality distribution criteria was assessed via a Shapiro-Wilk test. Bivariate schema was done via Ordinary one-way ANOVA with Dunnett's multiple comparisons post hoc test or Factorial ANOVA with Bonferroni's correction. To account for the variance homoscedasticity, a Levene test with a BrownForsythe correction was performed. Mammosphere circularity quantification was performed with a nonparametric $t$-test approach using the independent samples Mann-Whitney test. The results are presented as mean \pm SEM. Calculations of the $\mathrm{IC}_{50} \mathrm{~s}$ were done with doseresponse curve fittings using the non-linear regression parameter: dose-response - inhibition (log [inhibitor] vs normalized response). For gene expression studies in both TNBC cell lines, vehicle and GLE treatment were individually assessed using the $2^{(-\Delta C t)}$ formula by comparing their relative gene expression to the expression of the reference genes. The $p$-values for gene expression PCR array analysis was calculated based on one-way ANOVA of the replicate $2^{(-\Delta C t)}$ values for each gene in the control group and treatment groups. Statistical significance was set at $p \leq 0.05$; excluding the normality tests. All calculations were done using GraphPad Prism v6.0 (San Diego, CA, USA).

For in vivo experiments, a ten week (W1-W10) statistical model with two comparison groups was done as follows: vehicle and GLE $28 \mathrm{mg} / \mathrm{kg}$. Normality diagnostics were performed using the Shapiro-Wilk estimator. Frequencies, percentages, central tendency and dispersion measures were calculated to assess the raw distribution of the study variables. To account for the time horizon as a statistical unit, a General Linear Model Repeated Measures ANOVA (GLMRMA) approach was used in order to calculate estimated marginal means. A Mauchly's test of sphericity was performed to assess if our models have or not the assumption of compound symmetry. If non-significant, we report the univariate results with an Epsilon correction; if significant; we report the multivariate results using the Pillai's trace estimator. Either of the last explained factors was used to evaluate the time effect in our models. A test of between-subjects effect was applied to perceive statistical differences between the groups per block. The estimated marginal means will be reported. The significant level $(\alpha)$ was set to $\leq 0.05$, excluding normality test criteria. IBM Statistical Package for Social Sciences (IBM-SPSS, Chicago, IL, USA) v.23.0 for Windows was used. To assess mouse and tumor weight in our dataset, a normality diagnostic was performed using the Shapiro-Francia estimator. Central tendency measures and dispersion measures were calculated to evaluate the raw distribution. An independent sample $t$-test was performed to compare two comparison groups as follows: vehicle and GLE $28 \mathrm{mg} / \mathrm{kg} \mathrm{BW}$. Variance homoscedasticity was evaluated using the Levene protocol. The significant level $(\alpha)$ was set to $P \leq 0.05$; except for the normality and variance homogeneity tests. IBM Statistical Package for Social Sciences (IBM-SPSS, Chicago, IL, USA) v.23.0 for Windows was used.

\section{Author contributions}

Conceptualization and Methodology: Rios-Fuller TJ, Schneider RJ, Martínez-Montemayor MM. Software: Rios-Fuller TJ, Maldonado-Martínez G. Validation and Formal Analysis: Rios-Fuller TJ, Maldonado-Martínez G, Schneider RJ, Martínez-Montemayor MM. Investigation: Rios-Fuller TJ, Ortiz-Soto G, Lacourt-Ventura M, Martínez-Montemayor MM. Writing - original draft: Rios-Fuller TJ, Martínez-Montemayor MM. Writing - review and editing: Rios-Fuller TJ, Ortiz-Soto G, Lacourt-Ventura M, Maldonado-Martinez G, Cubano LA, Schneider RJ, Martínez-Montemayor MM. Funding Acquisition: Rios-Fuller TJ, Cubano LA, Schneider RJ, Martínez-Montemayor MM.

\section{ACKNOWLEDGMENTS}

The authors acknowledge the technical support provided by Pablo Lopez and Dr. Vanessa Rivera-Amill from Ponce Health Sciences University. We thank the members of Dr. Schneider's Lab for their help and support. We also thank Dr. Antonio Henrique Baccin Martins from University of Puerto Rico - Pharmacology and Toxicology Department, and Dr. Ivette J. Suarez-Arroyo from Universidad Central del Caribe - Department of Biochemistry, for their critical reading of the manuscript and advice during the course of this project. Finally, we thank the medical student from Universidad Central del Caribe (UCC), Alicia Marti, for her special help and technical assistance.

\section{CONFLICTS OF INTEREST}

No potential conflicts of interest were disclosed.

\section{FUNDING}

This study was financially supported by the Thesis Track grant and Post-Hurricane Maria Aid for Researchers grant from the Puerto Rico Science Technology and Research Trust, Ciencia Puerto Rico, and AAASCaribbean Division, to TRF and MMM, respectively. Grants from NIH/NIGMS GM110513 to UCC/TRF; Title V PPOHA \#P031M105050 and Title-V-Cooperative \#P031S130068 from US Department of Education to UCC; NIH/RCMI \#RR003035 and \#MD007583 to UCC/ MMM; NIH/SC3 \#GM111171 to UCC/MMM, and NIH R01CA178509, NIH R01CA207893, BCRF-16-143 to RJS. 


\section{REFERENCES}

1. Ismail-Khan $\mathrm{R}$, Bui MM. A review of triple-negative breast cancer. Cancer Contr. 2010; 17:173-76. https://doi. org/10.1177/107327481001700305.

2. Chavez KJ, Garimella SV, Lipkowitz S. Triple negative breast cancer cell lines: one tool in the search for better treatment of triple negative breast cancer. Breast Dis. 2010; 32:35-48. https://doi.org/10.3233/BD-2010-0307.

3. Paradiso A, Singer CF. Therapeutic Strategies in TripleNegative Breast Cancer. Breast Care (Basel). 2017; 12:6-7. https://doi.org/10.1159/000460238.

4. Gangi A, Chung A, Mirocha J, Liou DZ, Leong T, Giuliano AE. Breast-conserving therapy for triple-negative breast cancer. JAMA Surg. 2014; 149:252-58. https://doi. org/10.1001/jamasurg.2013.3037.

5. van Roozendaal LM, Smit LH, Duijsens GH, de Vries B, Siesling S, Lobbes MB, de Boer M, de Wilt JH, Smidt ML. Risk of regional recurrence in triple-negative breast cancer patients: a Dutch cohort study. Breast Cancer Res Treat. 2016; 156:465-72. https://doi.org/10.1007/ s10549-016-3757-4

6. Fajdic J, Djurovic D, Gotovac N, Hrgovic Z. Criteria and procedures for breast conserving surgery. Acta Inform Med. 2013; 21:16-19. https://doi.org/10.5455/aim.2013.21.16-19.

7. Collina F, Di Bonito M, Li Bergolis V, De Laurentiis M, Vitagliano C, Cerrone M, Nuzzo F, Cantile M, Botti G. Prognostic Value of Cancer Stem Cells Markers in Triple-Negative Breast Cancer. BioMed Res Int. 2015; 2015:158682. https://doi.org/10.1155/2015/158682.

8. Pires BR, De Amorim IS, Souza LD, Rodrigues JA, Mencalha AL. Targeting Cellular Signaling Pathways in Breast Cancer Stem Cells and its Implication for Cancer Treatment. Anticancer Res. 2016; 36:5681-91. https://doi. org/10.21873/anticanres.11151.

9. Shima H, Yamada A, Ishikawa T, Endo I. Are breast cancer stem cells the key to resolving clinical issues in breast cancer therapy? Gland Surg. 2017; 6:82-88. https://doi. org/10.21037/gs.2016.08.03.

10. Yang F, Cao L, Sun Z, Jin J, Fang H, Zhang W, Guan X. Evaluation of Breast Cancer Stem Cells and Intratumor Stemness Heterogeneity in Triple-negative Breast Cancer as Prognostic Factors. Int J Biol Sci. 2016; 12:1568-77. https://doi.org/10.7150/ijbs.16874.

11. Hadjimichael C, Chanoumidou K, Papadopoulou N, Arampatzi P, Papamatheakis J, Kretsovali A. Common stemness regulators of embryonic and cancer stem cells. World J Stem Cells. 2015; 7:1150-84.

12. Liu A, Yu X, Liu S. Pluripotency transcription factors and cancer stem cells: small genes make a big difference. Chin J Cancer. 2013; 32:483-87. https://doi.org/10.5732/ cjc.012.10282.

13. Dontu G, Wicha MS. Survival of mammary stem cells in suspension culture: implications for stem cell biology and neoplasia. J Mammary Gland Biol Neoplasia. 2005; 10:7586. https://doi.org/10.1007/s10911-005-2542-5.

14. Dontu G, Abdallah WM, Foley JM, Jackson KW, Clarke MF, Kawamura MJ, Wicha MS. In vitro propagation and transcriptional profiling of human mammary stem/ progenitor cells. Genes Dev. 2003; 17:1253-70. https://doi. org/10.1101/gad.1061803.

15. Li Y, Rosen JM. Stem/progenitor cells in mouse mammary gland development and breast cancer. J Mammary Gland Biol Neoplasia. 2005; 10:17-24. https://doi.org/10.1007/ s10911-005-2537-2.

16. Grimshaw MJ, Cooper L, Papazisis K, Coleman JA, Bohnenkamp HR, Chiapero-Stanke L, Taylor-Papadimitriou J, Burchell JM. Mammosphere culture of metastatic breast cancer cells enriches for tumorigenic breast cancer cells. Breast Cancer Res. 2008; 10:R52. https://doi.org/10.1186/ bcr2106.

17. Matsui WH. Cancer stem cell signaling pathways. Medicine (Baltimore). 2016; 95:S8-19. https://doi.org/10.1097/ MD.0000000000004765.

18. Banerjee $\mathrm{K}$, Resat $\mathrm{H}$. Constitutive activation of STAT3 in breast cancer cells: A review. Int J Cancer. 2016; 138:2570-78. https://doi.org/10.1002/ijc.29923.

19. Lin L, Hutzen B, Lee HF, Peng Z, Wang W, Zhao C, Lin HJ, Sun D, Li PK, Li C, Korkaya H, Wicha MS, Lin J. Evaluation of STAT3 signaling in ALDH+ and ALDH+/CD44+/CD24subpopulations of breast cancer cells. PLoS One. 2013; 8:e82821. https://doi.org/10.1371/journal.pone.0082821.

20. Wang ML, Chiou SH, Wu CW. Targeting cancer stem cells: emerging role of Nanog transcription factor. Onco Targets Ther. 2013; 6:1207-20. https://doi.org/10.2147/OTT.S38114.

21. Do DV, Ueda J, Messerschmidt DM, Lorthongpanich C, Zhou Y, Feng B, Guo G, Lin PJ, Hossain MZ, Zhang W, Moh A, Wu Q, Robson P, et al. A genetic and developmental pathway from STAT3 to the OCT4-NANOG circuit is essential for maintenance of ICM lineages in vivo. Genes Dev. 2013; 27:1378-90. https://doi.org/10.1101/ $\operatorname{gad} .221176 .113$.

22. Han J, Zhang F, Yu M, Zhao P, Ji W, Zhang H, Wu B, Wang Y, Niu R. RNA interference-mediated silencing of NANOG reduces cell proliferation and induces $\mathrm{G} 0 / \mathrm{G} 1$ cell cycle arrest in breast cancer cells. Cancer Lett. 2012; 321:80-88. https://doi.org/10.1016/j.canlet.2012.02.021.

23. Jin X, Ruiz Beguerie J, Sze DM, Chan GC. Ganoderma lucidum (Reishi mushroom) for cancer treatment. Cochrane Database Syst Rev. 2012; 6:CD007731. https://doi. org/10.1002/14651858.CD007731.pub2.

24. Zhu XL, Chen AF, Lin ZB. Ganoderma lucidum polysaccharides enhance the function of immunological effector cells in immunosuppressed mice. J Ethnopharmacol. 2007; 111:219-26. https://doi. org/10.1016/j.jep.2006.11.013.

25. Lin SB, Li CH, Lee SS, Kan LS. Triterpene-enriched extracts from Ganoderma lucidum inhibit growth of 
hepatoma cells via suppressing protein kinase $\mathrm{C}$, activating mitogen-activated protein kinases and G2-phase cell cycle arrest. Life Sci. 2003; 72:2381-90. https://doi.org/10.1016/ S0024-3205(03)00124-3.

26. Sliva D, Labarrere C, Slivova V, Sedlak M, Lloyd FP Jr, Ho NW. Ganoderma lucidum suppresses motility of highly invasive breast and prostate cancer cells. Biochem Biophys Res Commun. 2002; 298:603-12. https://doi.org/10.1016/ S0006-291X(02)02496-8.

27. Suarez-Arroyo IJ, Rosario-Acevedo R, Aguilar-Perez A, Clemente PL, Cubano LA, Serrano J, Schneider RJ, Martínez-Montemayor MM. Anti-tumor effects of Ganoderma lucidum (reishi) in inflammatory breast cancer in in vivo and in vitro models. PLoS One. 2013; 8:e57431. https://doi.org/10.1371/journal.pone.0057431.

28. Hu H, Ahn NS, Yang X, Lee YS, Kang KS. Ganoderma lucidum extract induces cell cycle arrest and apoptosis in MCF-7 human breast cancer cell. Int J Cancer. 2002; 102:250-53. https://doi.org/10.1002/ijc.10707.

29. Martínez-Montemayor MM, Acevedo RR, Otero-Franqui E, Cubano LA, Dharmawardhane SF. Ganoderma lucidum (Reishi) inhibits cancer cell growth and expression of key molecules in inflammatory breast cancer. Nutr Cancer. 2011; 63:1085-94. https://doi.org/10.1080/01635581.2011 .601845 .

30. Suárez-Arroyo IJ, Loperena-Alvarez Y, Rosario-Acevedo R, Martínez-Montemayor MM. Ganoderma spp.: A Promising Adjuvant Treatment for Breast Cancer. Medicines (Basel). 2017; 4:15. https://doi.org/10.3390/medicines4010015.

31. Jiang J, Slivova V, Harvey K, Valachovicova T, Sliva D. Ganoderma lucidum suppresses growth of breast cancer cells through the inhibition of Akt/NF-kappaB signaling. Nutr Cancer. 2004; 49:209-16. https://doi.org/10.1207/ s15327914nc4902_13.

32. Suárez-Arroyo IJ, Rios-Fuller TJ, Feliz-Mosquea YR, Lacourt-Ventura M, Leal-Alviarez DJ, Maldonado-Martinez G, Cubano LA, Martínez-Montemayor MM. Ganoderma lucidum Combined with the EGFR Tyrosine Kinase Inhibitor, Erlotinib Synergize to Reduce Inflammatory Breast Cancer Progression. J Cancer. 2016; 7:500-11. https://doi.org/10.7150/jca.13599.

33. Wu G, Qian Z, Guo J, Hu D, Bao J, Xie J, Xu W, Lu J, Chen X, Wang Y. Ganoderma lucidum extract induces G1 cell cycle arrest, and apoptosis in human breast cancer cells. Am J Chin Med. 2012; 40:631-42. https://doi.org/10.1142/ S0192415X12500474.

34. Shang D, Li Y, Wang C, Wang X, Yu Z, Fu X. A novel polysaccharide from Se-enriched Ganoderma lucidum induces apoptosis of human breast cancer cells. Oncol Rep. 2011; 25:267-72. https://doi.org/10.3892/or_00001070.

35. Kim TH, Kim JS, Kim ZH, Huang RB, Chae YL, Wang RS. Induction of apoptosis in MCF 7 human breast cancer cells by Khz (fusion of Ganoderma lucidum and Polyporus umbellatus mycelium). Mol Med Rep. 2016; 13:1243-49. https://doi.org/10.3892/mmr.2015.4655.
36. Jiang J, Slivova V, Sliva D. Ganoderma lucidum inhibits proliferation of human breast cancer cells by downregulation of estrogen receptor and NF-kappaB signaling. Int J Oncol. 2006; 29:695-703. https://doi.org/10.3892/ ijo.29.3.695.

37. Loganathan J, Jiang J, Smith A, Jedinak A, ThyagarajanSahu A, Sandusky GE, Nakshatri H, Sliva D. The mushroom Ganoderma lucidum suppresses breast-tolung cancer metastasis through the inhibition of proinvasive genes. Int J Oncol. 2014; 44:2009-15. https://doi. org/10.3892/ijo.2014.2375.

38. Parton M, Dowsett M, Smith I. Studies of apoptosis in breast cancer. BMJ. 2001; 322:1528-32. https://doi. org/10.1136/bmj.322.7301.1528.

39. Boulares AH, Yakovlev AG, Ivanova V, Stoica BA, Wang G, Iyer S, Smulson M. Role of poly(ADP-ribose) polymerase (PARP) cleavage in apoptosis. Caspase 3-resistant PARP mutant increases rates of apoptosis in transfected cells. J Biol Chem. 1999; 274:22932-40. https://doi.org/10.1074/ jbc.274.33.22932.

40. Androic I, Krämer A, Yan R, Rödel F, Gätje R, Kaufmann M, Strebhardt K, Yuan J. Targeting cyclin B1 inhibits proliferation and sensitizes breast cancer cells to taxol. BMC Cancer. 2008; 8:391. https://doi. org/10.1186/1471-2407-8-391.

41. Gkouveris I, Nikitakis N, Sauk J. STAT3 signaling in cancer. J Cancer Ther. 2015; 06:709-26. https://doi.org/10.4236/ jct.2015.68078.

42. Siveen KS, Sikka S, Surana R, Dai X, Zhang J, Kumar AP, Tan BK, Sethi G, Bishayee A. Targeting the STAT3 signaling pathway in cancer: role of synthetic and natural inhibitors. Biochim Biophys Acta. 2014; 1845:136-54. https://doi.org/10.1016/j.bbcan.2013.12.005.

43. Yuan J, Zhang F, Niu R. Multiple regulation pathways and pivotal biological functions of STAT3 in cancer. Sci Rep. 2015; 5:17663. https://doi.org/10.1038/srep17663.

44. Rane SG, Reddy EP. Janus kinases: components of multiple signaling pathways. Oncogene. 2000; 19:5662-79. https:// doi.org/10.1038/sj.onc.1203925.

45. Zheng Q, Banaszak L, Fracci S, Basali D, Dunlap SM, Hursting SD, Rich JN, Hjlemeland AB, Vasanji A, Berger NA, Lathia JD, Reizes O. Leptin receptor maintains cancer stem-like properties in triple negative breast cancer cells. Endocr Relat Cancer. 2013; 20:797-808. https://doi. org/10.1530/ERC-13-0329.

46. Yin X, Zhang BH, Zheng SS, Gao DM, Qiu SJ, Wu WZ, Ren ZG. Coexpression of gene Oct4 and Nanog initiates stem cell characteristics in hepatocellular carcinoma and promotes epithelial-mesenchymal transition through activation of Stat3/Snail signaling. J Hematol Oncol. 2015; 8:23. https://doi.org/10.1186/s13045-015-0119-3.

47. Marotta LL, Almendro V, Marusyk A, Shipitsin M, Schemme J, Walker SR, Bloushtain-Qimron N, Kim JJ, Choudhury SA, Maruyama R, Wu Z, Gönen M, Mulvey 
LA, et al. The JAK2/STAT3 signaling pathway is required for growth of $\mathrm{CD} 44^{+} \mathrm{CD} 24^{-}$stem cell-like breast cancer cells in human tumors. J Clin Invest. 2011; 121:2723-35. https://doi.org/10.1172/JCI44745.

48. Balko JM, Schwarz LJ, Luo N, Estrada MV, Giltnane JM, Dávila-González D, Wang K, Sánchez V, Dean PT, Combs SE, Hicks D, Pinto JA, Landis MD, et al. Triple-negative breast cancers with amplification of JAK2 at the 9p24 locus demonstrate JAK2-specific dependence. Sci Transl Med. 2016; 8:334ra53. https://doi.org/10.1126/scitranslmed. $\operatorname{aad} 3001$.

49. Abubaker K, Luwor RB, Zhu H, McNally O, Quinn MA, Burns CJ, Thompson EW, Findlay JK, Ahmed N. Inhibition of the JAK2/STAT3 pathway in ovarian cancer results in the loss of cancer stem cell-like characteristics and a reduced tumor burden. BMC Cancer. 2014; 14:317. https://doi. org/10.1186/1471-2407-14-317.

50. Wei W, Tweardy DJ, Zhang M, Zhang X, Landua J, Petrovic I, Bu W, Roarty K, Hilsenbeck SG, Rosen JM, Lewis MT. STAT3 signaling is activated preferentially in tumor-initiating cells in claudin-low models of human breast cancer. Stem Cells. 2014; 32:2571-82. https://doi. org/10.1002/stem.1752.

51. Galoczova M, Coates P, Vojtesek B. STAT3, stem cells, cancer stem cells and p63. Cell Mol Biol Lett. 2018; 23:12. https://doi.org/10.1186/s11658-018-0078-0.

52. Gawlik-Rzemieniewska N, Bednarek I. The role of NANOG transcriptional factor in the development of malignant phenotype of cancer cells. Cancer Biol Ther. 2016; 17:1-10. https://doi.org/10.1080/15384047.2015.1121348.

53. Robertson FM, Petricoin Iii EF, Van Laere SJ, Bertucci F, Chu K, Fernandez SV, Mu Z, Alpaugh K, Pei J, Circo R, Wulfkuhle J, Ye Z, Boley KM, et al. Presence of anaplastic lymphoma kinase in inflammatory breast cancer. Springerplus. 2013; 2:497. https://doi. org/10.1186/2193-1801-2-497.

54. Organ SL, Tsao MS. An overview of the c-MET signaling pathway. Ther Adv Med Oncol. 2011; 3:S7-19. https://doi. org/10.1177/1758834011422556.

55. Selander KS, Li L, Watson L, Merrell M, Dahmen H, Heinrich PC, Müller-Newen G, Harris KW. Inhibition of gp130 signaling in breast cancer blocks constitutive activation of Stat 3 and inhibits in vivo malignancy. Cancer Res. 2004; 64:6924-33. https://doi.org/10.1158/0008-5472. CAN-03-2516.

56. Bohrer LR, Chuntova P, Bade LK, Beadnell TC, Leon RP, Brady NJ, Ryu Y, Goldberg JE, Schmechel SC, Koopmeiners JS, McCarthy JB, Schwertfeger KL. Activation of the FGFR-STAT3 pathway in breast cancer cells induces a hyaluronan-rich microenvironment that licenses tumor formation. Cancer Res. 2014; 74:374-86. https://doi.org/10.1158/0008-5472.CAN-13-2469.

57. Jackson JG, Lozano G. TNBC invasion: downstream of STAT3. Oncotarget. 2017; 8:20517-18. https://doi. org/10.18632/oncotarget.15259.
58. Moreira MP, da Conceição Braga L, Cassali GD, Silva LM. STAT3 as a promising chemoresistance biomarker associated with the CD44+/high/CD24-/low/ALDH+ BCSCs-like subset of the triple-negative breast cancer (TNBC) cell line. Exp Cell Res. 2018; 363:283-90. https:// doi.org/10.1016/j.yexcr.2018.01.018.

59. Mukherjee S, Mazumdar M, Chakraborty S, Manna A, Saha S, Khan P, Bhattacharjee P, Guha D, Adhikary A, Mukhjerjee S, Das T. Curcumin inhibits breast cancer stem cell migration by amplifying the E-cadherin/ $\beta$-catenin negative feedback loop. Stem Cell Res Ther. 2014; 5:116. https://doi.org/10.1186/scrt506.

60. Ahonen I, Åkerfelt M, Toriseva M, Oswald E, Schüler J, Nees M. A high-content image analysis approach for quantitative measurements of chemosensitivity in patientderived tumor microtissues. Sci Rep. 2017; 7:6600. https:// doi.org/10.1038/s41598-017-06544-X.

61. Hernandez-Fernaud JR, Ruengeler E, Casazza A, Neilson LJ, Pulleine E, Santi A, Ismail S, Lilla S, Dhayade S, MacPherson IR, McNeish I, Ennis D, Ali H, et al. Secreted CLIC3 drives cancer progression through its glutathionedependent oxidoreductase activity. Nat Commun. 2017; 8:14206. https://doi.org/10.1038/ncomms14206.

62. Wang R, Lv Q, Meng W, Tan Q, Zhang S, Mo X, Yang $\mathrm{X}$. Comparison of mammosphere formation from breast cancer cell lines and primary breast tumors. J Thorac Dis. 2014; 6:829-37. https://doi.org/10.3978/j. issn.2072-1439.2014.03.38.

63. Xiong A, Yang Z, Shen Y, Zhou J, Shen Q. Transcription Factor STAT3 as a Novel Molecular Target for Cancer Prevention. Cancers (Basel). 2014; 6:926-57. https://doi. org/10.3390/cancers6020926.

64. Kim YJ, Kim JY, Lee N, Oh E, Sung D, Cho TM, Seo JH. Disulfiram suppresses cancer stem-like properties and STAT3 signaling in triple-negative breast cancer cells. Biochem Biophys Res Commun. 2017; 486:1069-76. https://doi.org/10.1016/j.bbrc.2017.03.164.

65. An H, Kim JY, Oh E, Lee N, Cho Y, Seo JH. Salinomycin Promotes Anoikis and Decreases the CD44+/CD24- StemLike Population via Inhibition of STAT3 Activation in MDA-MB-231 Cells. PLoS One. 2015; 10:e0141919. https://doi.org/10.1371/journal.pone.0141919.

66. Chen WJ, Ho CC, Chang YL, Chen HY, Lin CA, Ling TY, Yu SL, Yuan SS, Chen YJ, Lin CY, Pan SH, Chou HY, Chen YJ, et al. Cancer-associated fibroblasts regulate the plasticity of lung cancer stemness via paracrine signalling. Nat Commun. 2014; 5:3472. https://doi.org/10.1038/ ncomms4472.

67. Schneider CA, Rasband WS, Eliceiri KW. NIH Image to ImageJ: 25 years of image analysis. Nat Methods. 2012; 9:671-75. https://doi.org/10.1038/nmeth.2089. 